\title{
Between Islam, Politics, and Democracy: The Political Ideology of Partai Keadilan Sejahtera
}

\author{
Nostalgiawan Wahyudhi \\ Center for Political Studies \\ Indonesian Institute of Sciences
}

\begin{abstract}
This paper explores the political ideology of one of the most recent Islamic revivalist parties in Indonesia, the Partai Keadilan Sejahtera (PKS) or the Prosperous Justice Party. The rigidity and strong politico-ideological foundations of the PKS do not fit easily in contemporary Indonesian Muslim society; it is important to find the reasons why the PKS has become moderate in its approach to Indonesian politics. This examination of the PKS's ideology covers institutional development, political strategies and its attitude to democracy. The political drive of the party has its origins in its very basic ideology that links to the political character of the Muslim Brotherhood. The party uses a rational approach to the 'objectification' of Muslim needs in adapting from a homogenous to a pluralist society that naturally insists the party contextualise its ideology in building an Islamic state, $\operatorname{shari~}^{c} a$ implementation and democracy.
\end{abstract}

Keywords: PKS, Party ideology, Muslim Brotherhood, Islamic State, Sharī $a$ implementation

\section{INTRODUCTION}

In the complex history of Islam, religion plays a crucial role in conceptualising a political form and creating social structure. 'Islam proved to be a faith in which religion was harnessed to political power' (Esposito, 1998: 31-32). Muslims stand at the crossroads because of Islam's problematical relations with the state over such matters as political legitimacy, modernisation, authoritarian government and the wave of secularisation. The end of Suharto's authoritarian administration led to a new, free political environment, and the emergence of various new political parties. Among the new parties was a militant Islamic party, the Partai Keadilan Sejahtera (PKS) or the Prosperous Justice Party. At the first post-Suharto, democratic elections in 1999, the party gained only 1.36 per cent of the vote but its share increased to 7.34 per cent in the 2004 elections. Its share of votes at the 2009 elections stagnated; the party won only 7.88 per cent. The party's performance fell to 6.79 per cent in 2014 (Indonesian Electoral Commission, 2014).

According to Bubalo \& Fealy (2005), "the PKS represents one of the few genuine alternatives in Indonesian politics... [and represents] a tangible demonstration of how Islamists can sometimes assist a process of democratisation" within vastly corrupt existing parties. PKS offers a new style or paradigm in political behaviour that remarks a positive development for Indonesian democracy. It can be argued that this particular form of Middle Eastern influence has had a positive effect on Indonesian political life. The party's new platform represents the spirit of openness, pluralism and nationalism, which abandons its strong Islamic identity Fealy (2010).

In studying Islam and politics, some scholars use a 'cultural essentialist' approach that views culture as a prerequisite to the reception of democracy. Culture is an important factor in shaping the political environment. Prominent studies using a cultural approach are exemplified by the works of Max Weber (1974) on the mutual connection of religious traditions (that is, the Protestant Ethic) with the spirit of modernisation and capitalism; by Samuel P Huntington (1996) when he argues that a significant growth in cultural pressure will probably culminate in a clash of civilisations between a 
potential demographic surge of Muslim worlds and the West; by Bernard Lewis (2002: 3) on the assumption of Islam's rejection of Western modernity as a reflection of a centuries-long conflict between Islam and the Christian West; or by Francis Fukuyama who adheres to the view of Islam as a cultural factor that should be blamed for the incompatibility of democracy with the Muslim world (Al-Braizat, 2002). The cultural essentialist approach tends to the view that the slow progress of democratisation in the Muslim world is caused by a sterile political environment provided by Islamic culture. The major result of this approach is that it causes incompatible findings in academic circles and tends to easily stereotype the religious traditions (see Islam) as essentially democratic or undemocratic (Hilmy, 2010: 19).

Another approach that is more relevant in studying contemporary Islam in Indonesian politics is a structural-instrumentalist approach, which supersedes the view that religion is a determinant factor in social and political life. It is because religion is only an intervening variable within complex social and political configurations. The structural approach views agents, not religion, as a crucial factor in determining the extent of democratic acceptance. Sterile democratic progress in the Muslim world can be for non-cultural reasons, such as authoritarian regimes, standards education, interest groups and institutions and more (Hasenclever and Rittberger, 2000). The study by Stepan and Robertson (2004) finds that the non-Arab, Muslim-majority countries (including Indonesia) are almost twenty times more electorally competitive than are Arab countries. Stepan and Robertson probably recognise Fareed Zakaria's conception of 'Arab exceptionalism' in which democracy is not modified by religion (Islam) but perhaps by Arabic factors (the regime, interest groups and institutions) because democracy works fairly well in non-Arab countries.

The structural-instrumentalist approach views a political party as one of the actors or agents that is crucially important to energise the growth of democracy and is significant in the study of the dynamics of Islamic institutions in Indonesian politics. Based on this understanding, the emergence of the PKS in post-Suharto Indonesia is a very remarkable development and it is important that it be studied. This paper does not discuss the role of the PKS in the democratic process in Indonesia but examines in depth its moderate ideology as it affects institutional development, political strategies and its approach to democracy. Its ideology is important to an understanding of the current ideas that drive and characterise the party. Giovanni Sartori (2005: 27-28) links ideology to a belief system that is really a political-religious-philosophic-scientific system. Correlatively, a political belief system consists of the set of beliefs according to which individuals navigate and orient themselves in the sea of politics and offers a political and cultural blueprint for a particular social order. It also becomes a term associated with dogma and the manipulation of beliefs that can control and mobilise society (Festenstein and Kenny, 2005: 2-3). Therefore, a political ideology largely concerns itself with how to allocate power and to what ends that power should be used.

\section{THE DISCOURSE OF DA WA, POLITICS AND DEMOCRACY}

For the PKS, Islam is more than a set of obligatory rituals. As explained by Abū Aclā al-Mawdūdī, it embodies an integral and holistic belief system governing all aspects of living that provides a model for individual and political action (Ahmad, 1994: 464-468; Moten, 1993). Unlike the West, where the domains of religion (church) and politics (the state) are separate and coexist with their own distinct laws and chains of authority, Islam, as al-Ghazālī (1058-1111) points out, provides mutualinclusive relations between religion and politics.

In essence, the political orientation of the PKS is based on the political ideology of the Muslim Brotherhood. There are two reasons why the ideology of the Muslim Brotherhood is close to politics and why it affects the PKS. The Muslim Brotherhood was founded by Hasan al-Bannā at a time when the Muslim world was in upheaval and faced intense political exclusions under British colonialism (al-Qarḍ̄āī̄, 2003: 149-150; al-Qarḍāwī, 1983: 79). Al-Bannā believed that Islam and the independent state are mutually supportive. Islam provides the basic goods, that is, rules, 
directions, principles and emotions that drive a nation to be independent. This led him to the opinion that the Muslims' struggle to achieve the independence of their state in all Muslim lands is a struggle for human rights, freedom, and faith (Hawa, 1988: 57-58; al-Bannā, 1983: 160). Furthermore, in his discussion on nationalism, al-Bannā argued that Islam also feeds the spirit of nationalism based on the principle of faith, particularly at the state level, and generally through Muslim lands (al-Bannā, 2007: 112-119). From the perspective of the Muslim Brotherhood, its emergence as an institution is a reflection of the spirit of nationalism, nationhood and faith (Islam), where these are part of the responsibility of Muslims to their country and religion (al-Qarḍāwī, 2003: 130-138); and nationalism has to be defined beyond political ends but it is part of faith, blood and the material struggle to establish Islam on earth (al-Bannā, 2007: 37). ${ }^{1}$

In the further political development of Egypt, al-Bannā agreed that democracy is important for Muslims because undemocratic political systems strive to exclude Muslim participation in politics (Nu'man, 2003: 46). ${ }^{2}$ This assumption is based on the reality that a democratic political system provides a free political environment (al-Bannā, 2007: 155-157), which helps the rapid growth of socio-political movements in the Muslim world. ${ }^{3}$ This condition, according to Anis Matta, determines that democracy takes precedence over Muslim politics and rights. Preserving the role of democracy in Muslim countries is essential. It is about how Islam understands and treats democracy that, in reality, eradicates the friction between it and the state (Matta, 2006: 76). The role of the PKS in the democratic process provides an example of how Islam practises politics, and it also verifies that democracy is the most effective means for advocating Muslims' rights in politics (DPP-PKS, 2007b: 83).

Second, the Muslim Brotherhood believed that the government is part of the caqidah and principles; rules $\left(\operatorname{shari}^{c} a\right)$ and implementation (governance and policy). The Muslim scholar must not be passive should the government (executive) violate the rules of God and deprive Muslims of their civil rights (al-Qardāwī, 1997: 265). ${ }^{4}$ The ikhwān (brothers, the members of the Muslim Brotherhood) are to take over the ruling government as part of their manhaj (strategy or method) (alQarḍāwī, 1997: 236-240; Gharīsah, 1988: 47). This concept is derived from the principle of shumūl al- ${ }^{c}$ aqüdah al-islämiyyah (the comprehensiveness of Islamic faith) that provides the understanding of shumūliyat al-Isläm (the universality of Islam). It explains that Islam is a divine religion that provides a comprehensive way of life (al-Qarḍāwī, 2003: 144-145). ${ }^{5}$ Islam, in a broader definition, is a nation-state, government and ummah (citizen), society, akhlāq (piety) and power, love and justice, civilisation and rule, knowledge and its source, jihād (struggle) and da $\mathcal{w}_{w}$ (proselytising, promoting the faith), and thought, all in one (Prayitno, 2002: 2; al-Bannā, 2007: 184-192; alQarḍāwī, 1983: 40-41).

1 For al-Banna, nationalism and patriotism are values that have to be seeded in the souls of Muslims because those are part of Islamic teaching. Islam needs Muslim countries to be strong in the spirit of togetherness, not in narrow, territorial nationalism (al-Qar $\square \bar{a} w \overline{1}$ 1983: 140; al-Bannā 1983: 88-89).

2 Al-Bannā's argument is supported by Ma'mūn al- $\square$ udaybī, one of the chairmen of the Muslim Brotherhood. He believes that democracy benefits Islam. As long as the system gives a chance to the party (even a little chance) to reform the government into a better one, the Muslim Brotherhood proudly takes part in democracy.

3 In a particular discussion, al-Bannā urges the unification of Muslim political organisations. He denies that a multiparty system is the only way to drive a country to be more democratic becauss he believes that a democratic country can be developed through a single party system with strong civil societies that are widely overseen by NGOs and non-profit institutions, which protect freedom of expression, speech, and self-determination (al-Bannā 2007: 263-264).

4 In this concern, Yūsuf al-Qar'āwī recognises the opinion of Ibn Taymiyya that a Muslim may not abandon politics (government) if this would enable a bad leader ('älim) to misuse his power for eveil.

5 Yūsuf al-Qar'āwī explains that the universality of Islam is an essential tenet of the teachings of Hirā' (min wa $\square y$ al$\left.\square i r \bar{a}^{\prime}\right)$, which was the matter of the first revelation to Prophet Muhammad (p.b.u.h). Islam is the message that extends over the past, present, and future, comprehending all affairs today and in the future. 
Furthermore, Anis Matta argues that the Prophet Muhammad (p.b.u.h) had used many political strategies. The political environment in Mecca and Medina during his time was decisively influenced by the power of the Quraysh clan, which had always imposed hard political pressures and constraints on Muslims. To improve this condition, the Prophet (p.b.u.h) made a strategic decision to recruit several prominent leaders from the Quraysh clan to increase the power and pride of the Muslims (Matta, 2006: 73). Matta's argument is supported by Abu Ridha, who points out that the work of Ibn Taymiyyah clearly explains that power and authority are important to regulate al-'amr bi al-ma ${ }^{C} \bar{u} f$ wa al-nahi ${ }^{c}$ ani al-munkar (enjoining good and opposing vice). Avoiding the weightiness of politics will reduce the possibility of maximum achievements in $d a$ wa (Ridho, 2004: 57). It is clear, for the above reasons, that the PKS and the Muslim Brotherhood have a natural tendency to be involved in politics.

\section{THE UNITY OF $D A^{\mathscr{C} A}$ AND POLITICAL INSTITUTIONS}

The transformation of the Tarbiyah movement (a $d a$ wa institution) into a political party, the PKS, was not to abandon its proselytising mission but to advocate the unification of the da $w a$ and political institutions (al-hizb huwa al-jam $\bar{a}^{c} a h$ wa al-jam $\bar{a}^{c}$ ah hiya al-hizb). The PKS is neither an apolitical $d a q_{w a}$ institution nor a purely pragmatic political institution; the party manifests the combination of social and political institutions (a socio-political institution of $d a w a$ ) (MPP-DPP, 2008: 54-55).

It is useful to ask why the PKS prefers to unite $d a{ }^{w} w$ with political institutions rather than make the political party a wing organisation (semi-autonomous body). The party's most influential ideologue, Hasan al-Bannā, opined that government (politics) is one of the foundations of the Muslim Brotherhood's ideology (al-Bannā, 2007: 237; Hawa, 1988: 29-30). ${ }^{6}$ The Brotherhood was inspired by the struggles of the Prophet Muhammad (p.b.u.h), which combined the earthly process of ${ }^{c} a q \bar{l} d a h$ (faith) in the Meccan phase and leading government (politics) in the Medinan phase. It continued during the time of al-khulafa' al rāshidūn (the first four caliphs). These give the best example of the unification of $d a$ wa with political institutions. To strengthen his argument, Hasan alBannā cited the speech of ${ }^{c}$ Uthmān (the third caliph), 'Allah prevents (evil) with power (politics) if they cannot be defended by the Qur'an' (al-Bannā, 2007: 237).

According to Anis Matta, the political history of the Prophet Muhammad (p.b.u.h) in Mecca and Medina was a clear transformation of a $d a$ wa to a political movement (the Medina state), which has been pursued by the Muslim Brotherhood as well as the PKS. He believes that the prototype of the Medina state was in the mind of the Prophet Muhammad (p.b.u.h) from the early years of Islam (when it was a $d a{ }_{w a}$ movement). He also argues that the importance of building the state was driven by the willingness of the Prophet (p.b.u.h) to expand the power of Islam vis-à-vis other political powers and civilisations (Matta, 2006: 1-6).

The PKS's decision to transform a da wa movement to a political party was a product of the democratic values within its systems. The transformation of the PKS was a bottom-up process started by conducting a survey to know the aspirations (amānah) of its cadres. The survey illustrated the high profile of the democratic values among the Tarbiyah activists: the new party was not the outcome of an individual initiative but the fruits of ${ }^{c}$ amal jama $\bar{q} \bar{l}$ (collective participation), cumulative aspiration and openness (Damanik, 2002: 230). ${ }^{7}$

6 Another work notes that the role of the Muslim Brotherhood in the Muslim world has been a sign of the awakening of Islamic politics (al-siyāsah al-islāmiyyah). It is about a tajdìd movement, the reformation of Muslim life ( $\square$ awa 1988: 29-30).

7 The Tarbiyah movement sought advice from the grassroots using a questionnaire that it distributed among its own cadres. The result was an 86 per cent majority that favoured the formation of a political party. The survey was of oncampus and non-campus cadres (the campus alumni): of 6000 questionnaires, approximately 5800 were returned to 
However, for the Tarbiyah activists, it is not the end of $d a$ wa movements. The political party is an instrument to pursue the goals of $d a{ }^{2} w a$, or 'part of $d a$ ' $w a$ at the institutional level' (government) because the state is the strongest political entity in society. For the PKS, a political party is another form of a $d a$ wa institution (MPP-DPP, 2008: xxi). Abu Ridha assumes that the PKS's $d a$ wa in post-Suharto Indonesia is a phase to realise the idea of Islamisation, because it harmonises the relations between Islam and politics. It will reduce a step in awakening Islamic haḍara (civilisation). At least, it is a demonstration of Islam and its values, that is, morality, responsibility and justice in the dawlah (the state) (Ridha, 2004: 55), are to reform the political culture (budaya berpolitik) among Muslims (DPP-PKS, 2007b: 97). ${ }^{8}$

The PKS's decision to unite $d a$ q $a$ and political activities simplified the issues of management, human resources, control and strategies of the party; it has become a much more effective organisation because management has been unified. But because management has been unified, the combining of these two institutions might create risks. First, by becoming a political party, it possibly shifts the mission of $d a{ }_{w a}$ to be more focused on pragmatic campaigns in pursuit of its political ends. It is confusing in the implementation of its cadre system: either the PKS Islamises the people to encourage deeper religiosity or it simply politicises its cadre system to gain more constituents. Second, it takes more time and energy to administer and coordinate political movements with their tricky intrigues than it does to prepare $d a{ }_{w a} a$ and its exhausting activities. Third, it is fragile: if the party collapses in the political arena, defeated by political intrigues or weakened by the faults of its politicians and the decisions that have been made, the institution will be less attractive to Muslims, even though it reprises its form as a pure $d a$ wa institution.

\section{THE FORMATION OF A DA WA PARTY}

The party strongly endorses Islam as its sole ideology. However, the PKS has officially submitted itself, under the constitution of the Republic, without highlighting the position of the Pancasila (the basic statute of the PKS, articles 1 and 3). The objective of the party is to realise a religious, civil society (masyarakat madani, a Medinan-like society) that pleases God. ${ }^{9}$ The party clearly states that the 'PKS is a religious propagation party (partai dakwah, a $d a$ wa party) whose objective is to realise a just and prosperous society, approved by Allah, in the Republic of Indonesia (NKRI)' (the basic statute of the PKS, article 5). It is driven by its awareness of the blessed momentum of the 1998 reformation that called upon Muslims to be involved in the development of the country. This motive has inspired the PKS to take it as a predicated responsibility (amānah al-da $w a$ ) to realise the universal vision and mandate for the political aspirations of all Muslims (MPP-DPP, 2008: 1). ${ }^{10}$ The

the central board. Of the respondents, 24 per cent disagreed with the drive to form a political party and wanted the Tarbiyah as it was. This result encouraged the Tarbiyah leaders from different backgrounds to proudly move to the mi $\square$ war mu'assasī phase (political participation [al-mushārakah al-siyāsiyyah]) by declaring the formation of the Justice Party (Partai Keadilan) on 9 Jumāài al-Ūlā 1423 H (20 July 1998).

8 The reformation of budaya berpolitik refers to the gradual shift of the culture of dilayani (served by the people) among politicians to become melayani (serving the people).

9 This is commonly known among Indonesians as masyarakat madani, a term that is often used and translates simply 'civil society'. Basically, it refers to a democratic and religious society modelled on the Medina state of the Prophethood. In Indonesian discourse, the word 'madani' has complex definitions. According to AS Hikam and Nurcholis Madjid, madani is taken from the Arabic word madani (civilised) or madaniyyah (civilisation) and. philosophically. the word refers to Medina (Madinah) which means wishing to be a Medinan-like society, which was a sign of the emergence of civilised society after uncivilised or backward society before Islam (jahiliyyah) (Madjid, 1996; Hikam, 1999). In a broader sense, the PKS defines masyarakat madani as the highly civilised and advanced society that elaborates the essence of values, norms, laws and morality from the faith, and respects pluralist, open and democratic society (MPP-DPP 2008: 1).

10 The universal vision is stated in the preamble of the Indonesian Declaration of Independence and promotes peace, social justice, education, security and human rights (MPP-DPP 2008: 1). 
party believes that its objective is to achieve its vision of a respected, prosperous and just society (MPP-DPP, 2008: 2-4).

According to Masdar Hilmi, the PKS has defined some distinctive concepts about political Islam and Islamic politics. What the PKS seems to display on the political stage is different from the usual manifestation of political Islam. Political Islam refers to the attitudes of 'Muslim democrats' whose main goals in politics are more mundane and pragmatic, that is, to manipulate Islam to meet particular economic, political and social interests (Nasr, 2005). ${ }^{11}$ It is something about Islamic politics that basically contains a religious predication or motivation in politics, which views politics as a field of $d a q_{w a}$, the purpose of which is to serve the people and empower them by virtue of religious values. It does not make power the only end of politics. For the PKS, Islamic politics should take precedence over political Islam. The politicisation of Islam must be replaced by the Islamisation of politics. Through this concept, the PKS has defined itself as a revivalist party in the Archipelago (Hilmy, 2010: 179-203).

The above analysis is criticised by Yūsuf al-Qardāwī. If the PKS is still consistent with the Muslim Brotherhood's ideology, it is not merely a manifestation of Islamic politics but a reflection of the universality of Islam in which politics is a natural part of religion (al-Qardāwī, 2003: 216219). Qarḍāwi argues that this is neither manipulation nor the creation of a new type of politics but is bringing back Islamic traditions to politics, traditions that have been profaned since the time of Western colonisation of Muslim lands. It is why a $d a$ wa party has to be established in Muslim countries. For this special mission, according to Hilmi Aminudin, a da wa party in contemporary politics has to prove and unite all elements of religious propagation with a professional political party (Aminudin, 2008: ii-iii). ${ }^{12}$

\section{THE STRATEGY OF THE PKS IN INDONESIAN POLITICS}

For the PKS, a da wa is a transformative process (proses transformasi). It manages activities to transform individuals and society from backwardness (al-jāhiliyyah) to Islamic life in line with the principles of Islam. The PKS describes this in its $d a$ wa grand strategies in which the party has a transformasi mission to change today's society (masyarakat saat ini) to the PKS's ideal society (masyarakat madani). The PKS prefers to regulate its transformasi mission in a safe way, in which the process will work legally within the Indonesian constitution, the party's basic statute, strategic planning, and its Basic Movement Philosophy (Falsafah Dasar Perjuangan) (MPP-DPP, 2008: 37).

The grand strategy of da wa (al-khuțutt al- ${ }^{c}$ arị̂hah) of the PKS mainly emphasises a transformation that is indicated by two major levels: individuaocial level and cultural-structural level

11 Nasr discusses the distinctions between Islamists (read revivalist) and Muslim democrats, who tend to use Islam as a potential source for grafting stable governing coalitions and political positions. The revivalists view politics and its democratic roles as not deeply legitimate but, at best, an instrument that might be useful in gaining power to build an Islamised state. Thus by being involved in politics, they do not practice political pragmatism, but rather demonstrate piety in politics (Islamic politics).

12 These elements can be divided into two groups: structural and material elements. The former reflect the cohesiveness of a $d a$ 'wa and political institution at the structural and managerial levels that manifest the spirit of unity and solidarity (wi'dah). Aminudin describes about seven scopes of wi'dah, that is, wi'dah al- 'aqidah (the unity of faith), wi'dah al-fikrah (the solidarity of thought and ideology), wi'dah al- 'arakah (the solidarity of movements), wi'dah almanhaj (the solidarity of methods), wi'dah al-ghayah (the unity of vision), wi'dah al-jamā'ah (the solidarity of institution) and wi'dah al-qiyādah (the unity of leadership). On the other hand, a da'wa party has to fulfil the capacity (al- 'ajm) of 'readiness' of its human resources (cadres and members) to take over the political mandate (al-amānah al-siyāsiyah) from the people. The capacity that has to be fulfilled by a da'wa party is the capacity of morality (al-

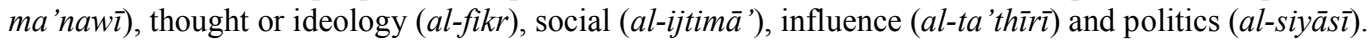


(see Figure 1). ${ }^{13}$ First, the most basic transformation is an individual transformation that is shown by a process of personal development of Muslims (al-shakhșiyyah al-islämiyyah) as an accelerator to further transformation, that is, a social transformation. This principal is based on the Qur'anic recitation (al-Anfāl (8): 53) that 'God will never change the grace which he hath bestowed on a people until they change what is in their (own) souls'. At the social level, a da wa has to cover broader work in society, which is more pluralist and dynamic. It has to be more adaptive in terms of strategies and developments that lead to no exception to being conservative in picturing the $d a$ $w a$ 's field. This means that the PKS has to be moderate and flexible, and has to adopt a comprehensive perspective of $d a{ }_{w a}\left(a l-d a \mathcal{w}_{\text {wh }}\right.$ al-shamilah) that will enable it to assist the dynamic changes of society (MPP-DPP, 2008: 36). This principle allows the PKS to shift its da wa strategies into politics as long as it determines the most important and crucial aspect in society.

Figure 1. The grand da wa strategy of the PKS

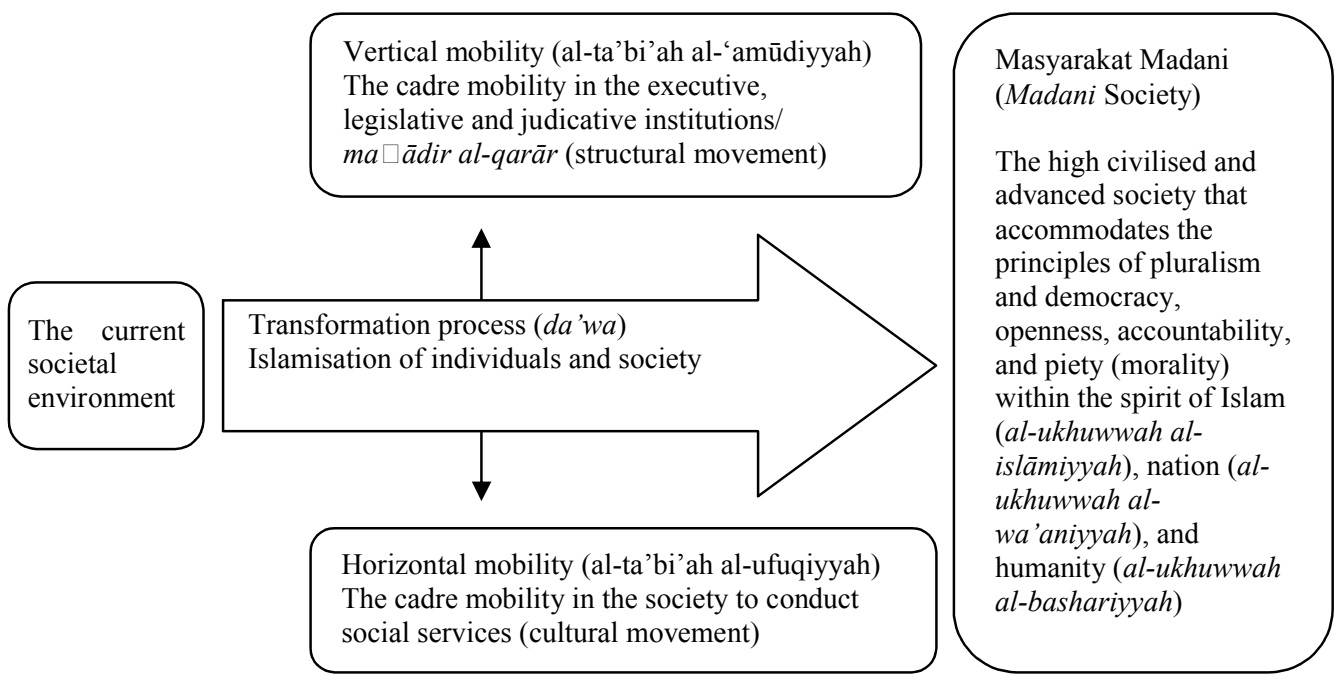

Source: MPP-DPP, Memperjuangkan Masyarakat Madani, edited by MPP-DPP (Jakarta: MPPPKS, 2008: 38).

Second, as a $d a$ wa party, the PKS has a comprehensive strategy of transformasi, which leads to horizontal and vertical mobilisation. The former is a cultural movement (gerakan kultural) that functions as a horizontal mobilisation strategy (al-ta Gi'ah al-ufuqiyyah) at the societal level (individuals and social institutions or mașädir al-quwwah) to win the hearts of the people and cause them to support the party's manhaj (method) and policies through the economic, social, cultural, gender, and environmental issues. The vertical mobilisation is a structural movement. It is the most strategic goal for a $d a{ }^{w} w$ party to generate vertical mobilisations that approach the strategic political institutions or decision makers (mașādir al-qarār) such as the executive, judicative and legislative bodies within democratic processes (elections) in the country. The strategic political institutions in the state and society are important for the transformasi strategy ( $d a$ wa strategy) to legally support the implementation of the values and principles of Islam in public policies. It is part of the constitution of the party to serve, develop and lead society (MPP-DPP, 2008: 37-39).

13 Conceptually, this process can also be defined as the Islamisation strategy of the PKS. As long as the transformation is part of the PKS's plan to advance the da'wa strategy, it can be associated with the Islamisation process, which, in essence, reveals the universal values of Islam (MPP-DPP 2008: 70-72). 
The context in which this grand strategy can be successfully accomplished is influenced by the party's mobilisation strategy in three main sectors, that is, the public sector, the private sector and the 'third' sector (MPP-DPP, 2008: 41). The mobilisation in the public sector is strongly correlated with structural movements (vertical mobilisation), which are mainly the political sector (executive, judicative, legislative bodies and bureaucracy) that is directed by decision makers and government employees. Mobilisation in this sector is important to support the top-down transformation. Meanwhile, the mobilisation of the rest, private and 'the third' sectors, supports the bottom-up transformation of $d a \mathfrak{w a}$. These sectors are basically socio-economic sectors that are populated by profit institutions and lembaga swadaya masyarakat (NGO). These sectors are important to strengthen the development of a civil society that is populated by professionals, businessmen, academics, activists, and educated and ordinary people (MPP-DPP, 2008: 39-43).

To realise the above grand strategy, the PKS follows the dimensions of $d a$ wa (mahâwir al$d a q_{w a}$, gradual ideological development to transform societies. The PKS believes that in every single step or dimension of a $d a \mathcal{G}$ wa there are aims and people (likulli marhalatin ahdāfuhā wa likulli marhalatin rijāluhā). According to Zulkieflimansyah, the characteristics of this mihwwar are not stagnant but continue to another broader dimension of responsibility and leadership (Zulkieflimansyah, 2008). For the PKS, mahāwir al-da $w a$, the dimensions of $d a \mathcal{q}_{w a}$, are based on the ideology of the Muslim Brotherhood, which emphasises four developments: mihwar tanzimi (personality), mihwar sha ${ }^{\prime} \bar{\imath}$ (society), miḥwar mu'assasī (politics) and miḥwar dawlī (the state) (Hawa, 1988: 62-84). ${ }^{14}$

First, mihwar tanzimin is the step for internal consolidation and cadre development (pembinaan kader). It covers the development of the cadre's personality and family to strengthen the internal foundation of the party by having qualified and loyal cadres. The PKS argues that it builds a strong Muslim character (al-shakhșiyyah al-islāmiyyah) (MPP-DPP, 2008: 51). Second, mihwar sha $b \bar{l}$, which is basically the party's role in society to promote openly the manhaj of the party (societal development) in al-marhalah al-jahriyyah al-jamāhiriyyah (the open and popular stage). The important key for this dimension is social service through charities, community development and advocacies. (MPP-DPP, 2008: 52).

Table 1. The dimensions of $d a$ 'wa, capability and strategies of the PKS

\begin{tabular}{|c|c|c|c|c|}
\hline \multirow{2}{*}{ Characteristics } & \multicolumn{4}{|c|}{ The dimensions of $\mathrm{Da}^{\mathrm{c}} \mathrm{wa}$ (Maḥāwir al-Dac $\left.{ }^{\mathrm{c}} \mathrm{wa}\right)$} \\
\hline & Tanẓimmī & Sha $\bar{b} \bar{\imath}$ & Mu'assasī & Dawlī \\
\hline Orientation & Tajnīd & $\begin{array}{l}\text { Khidmah al- } \\
\text { ummah (social } \\
\text { services) }\end{array}$ & $\begin{array}{l}\text { Mihanī fan̄̄ wa } \\
\text { takhașșus } \\
\text { (technical expertise } \\
\text { and specialisation) }\end{array}$ & $\begin{array}{l}\text { al-Idārah al- } \\
\text { dawliyyah (the } \\
\text { state } \\
\text { administration) }\end{array}$ \\
\hline $\begin{array}{l}\text { Strategy and } \\
\text { instruments } \\
\left({ }^{c} \text { amal }\right)\end{array}$ & $\begin{array}{l}\text { Halaqah } \\
\text { (meetings) }\end{array}$ & $\begin{array}{l}\text { Mobility in the } \\
\text { three sectors }\end{array}$ & $\begin{array}{l}\text { Mobility in the } \\
\text { three sectors }\end{array}$ & $\begin{array}{l}\text { Mobility in the } \\
\text { three sectors }\end{array}$ \\
\hline
\end{tabular}

14 These dimensions are adapted from the book of Risālah al-Ta $\square \bar{a} l \bar{\imath} m$ of $\square$ asan al-Bannā. He describes the manhaj al$d a \square w a$ (the $d a \square w a$ strategy) of the Muslim Brotherhood as a gradual movement that will follow the structure of the society. It starts from the individual, family, society, governance, and the state (al-dawlah al-islämiyyah) as the greatest achievement for the Muslim Brotherhood. The details of the strategy and instruments to achieve this mission are described in chapter $\mathrm{V}$ of this book. Al-Bannā also distinguishes the levels of $d a \square w a$ : Ta'rif, spreading the idea (fikrah) to the society by $\square$ alaqahs (study circles) and social services; Takwin, choosing qualified and loyal cadres; and Tanfidh, consistency and strength in the $d a \square w a$ movement (istiqämah). 


\begin{tabular}{|l|l|l|l|l|}
\hline Success criteria & $\begin{array}{l}\text { Encourage the } \\
\text { number of } \\
\text { cadres }\end{array}$ & $\begin{array}{l}\text { Social } \\
\text { acceptability } \\
\text { (moral and social } \\
\text { credibility) within } \\
\text { horizontal } \\
\text { mobility }\end{array}$ & $\begin{array}{l}\text { Advancing } \\
\text { professionalism } \\
\text { (vertical mobility) }\end{array}$ & National leadership \\
\hline $\begin{array}{l}\text { Public } \\
\text { accountability }\end{array}$ & $*$ & $* *$ & $* * *$ & $* * * *$ \\
\hline $\begin{array}{l}\text { Qualifications of } \\
\text { human resources }\end{array}$ & $\begin{array}{l}\text { Takwiners } \\
\text { (qualified and } \\
\text { loyal cadres) }\end{array}$ & Social activists & $\begin{array}{l}\text { Professionals and } \\
\text { specialists }\end{array}$ & Statesmen \\
\hline Management & Instruction & Consultation & Delegation & Participation \\
\hline
\end{tabular}

Source: MPP-DPP, Memperjuangkan Masyarakat Madani, edited by MPP-DPP (Jakarta: MPPPKS, 2008: 54).

With these social services in society, the party launched al- ${ }^{c} \bar{A} m$ al-Tarbawi (the year of education and development) in May 2000. The objective of this programme was to re-energise the process of tarbiyah (halaqah) to recruit new cadres, increase the quality of the cadres, and promote the tawsiyah (advising) tradition. It enabled the party to reach the required capability in social agendas: reconstructing the social environment (siyāghah al-bina al-ijtim $\bar{a} \mathfrak{q})$, preserving the good values in society (ri ${ }^{c} \bar{a} y a h$ al-mașāih al- ijtimā iyyah), solving societal problems (hal al-qaḍayā alijtimā $\overline{a y y a h)}$ and strengthening social solidarity (taqwiyyah al-taḍ̄mun al-ijtimā $\bar{\imath}$ ) (Tarbiyah weekly, 24 October 2007).

By strengthening its position in society, the party is enabled to transform itself for the milhwar mu'assasi (the dimension of politics). This dimension is defined by the PKS as the involvement of the party in public institutions, which can be divided into two sectors: first; parliamentary da wa' (dakwah parlementer) in the legislatures; and second, bureaucracy da 'wa' (dakwah birokrasi) in the executive, bureaucracy, judicature and other professional and strategic positions. ${ }^{15,}{ }^{16}$ The important key for this dimension is expertise and professionalism. The party strongly needs to maximise the capability of the cadres to penetrate the public institutions to affect, reformulate and implement government policy in line with Islam (MPP-DPP, 2008: 52-53). In addition, the mi hwar dawli is a step toward involvement in national leadership or state governance. However, at this dimension, the PKS has to establish a state, which is governed by the basic principles and values of Islam ( $\left.\operatorname{shari}{ }^{c} a\right)$, and to strive for the re-emergence of Islam at the forefront of world civilisation ('Idad, 1999: 9; Ridho, 2004: 55; Matta, 2002). ${ }^{17}$

15 The parliamentary da'wa (dakwah parlementer) is basically the party's role in the legislative body. Either the party becomes an opposition or collaborates with the government; the function of the party in the parliament is for legislation (taqnīn), checks and balances ( 'isbah) and public statements (tabligh) (MPP-DPP, 2008: 53).

16 The bureaucracy da'wa (dakwah birokrasi) is derived from the understanding of a da'wa in the strategic decisive institution to reform the governance system. The functions involved for this sector are first, to affect, reformulate and implement the government's political programmes in line with Islam; second, public services; third, a reformative mission to have good and clean governance; and fourth, vertical mobility of the party's cadres (MPP-DPP 2008: 5354).

17 This motivation is also one of the seven general missions of the Muslim Brotherhood's activities that were written by 'asan al-Bannā in the Risālah al-Ta'àlìm ('awa, 1988: 61). 


\section{DEALING WITH THE ISSUE OF ISLAMIC STATES AND SOCIETAL REALITIES}

Over the centuries, development of Islam in the Archipelago involved peaceful dialogues and embodied the spirit of 'Islamic nationalism' (proto-nationalism) that was exercised during the Dutch colonial period in these Muslim lands. ${ }^{18}$ In modern Indonesia, Islam maintains itself as the most important aspect of Indonesian politics, which is implicit in the preamble of the Indonesian Declaration of Independence, Pancasila and the presidential decree of 1959. ${ }^{19}$ Islam has acculturated into Indonesian cultures (akulturasi budaya), which comprise 250 ethnicities, and hundreds of languages and islands that were united to become a new country, Indonesia.

The PKS understands that the conflict between Islam and the state through separatism, radicalism, rebellions and riots is the outcome of ideological crises in Indonesia. ${ }^{20}$ Past regimes (of Soekarno and Suharto) used destructive policies to suppress Islam, which had naturally integrated with Indonesian cultures and life and assumed a leading role. The political marginalisation of Islam and its suppression militarily led to the eradication of Muslims' political representation. In addition, it dwarfed the real potentialities and capabilities of Indonesians because more than 80 per cent of the country's population are followers of Islam (MPP-DPP, 2008: 67-68). ${ }^{21}$ This concern has been highlighted by Hilmi Aminudin (the chairman of the PKS's Majelis Shura) who wrote

...this mindset, manipulating Indonesia to become an irreligious state, a secular state, that radically disassociates religion from the state, is a fatal conception that denies the historical facts and cultures of Indonesia as a Muslim nation. This absurdity is not relevant, because Indonesia recognizes tawhìd (superiority of God), the one and only God, in which the people are very religious, (and Indonesia is) the nation and Muslim country that is based on the one and only God (Aminudin, 2008: v).

18 From the 17 th century, the resistance by native Muslims to Dutch colonialism was spearheaded by the 'ulamā' and their santris (the madrasah students), by Islamic kingdoms and by the pribumi Muslims. The resistance resulted in such conflicts as the Ternate war (1635-1646 CE), the Makassar war (1660-1669 CE), the Trunojoyo war (1675$1679 \mathrm{CE})$, the Banten war (1680-1682 CE), the Cirebon war (1802-1806 CE), the Palembang war (1812-1816 CE), the Paderi war (1821-1838 CE), the Diponegoro war (1825-1830 CE), the Banjarmasin war (1859-1862 CE), and the Aceh war (1872-1908). The wave of Islamic nationalism was also seen in the struggle of the Sarekat Islam in modern Indonesia (Benda, 1955; van Dijk, 2007; Alfian, 1987; MPP-DPP, 2008: 61-63).

19 Several sentences strengthen the position of Islam and indirectly reflect the role of Islam in the country's development, such as 'under the blessings of Allah' (atas berkat rahmat Allah) are recorded in the preamble of the Indonesian constitution. Others are the one and only God (Ketuhanan yang Maha Esa) in the Pancasila and the presidential decree of July 1959, accepting the embodiment of the Piagam Jakarta in the Indonesian constitution (MPP-DPP, 2008: 65).

20 Under the regimes of Soekarno and Suharto, the Islamic nationalism that had embodied society had been challenged by the secular-nationalist ideology, which tried to avoid the aspirations of Muslims in the country. The debates over Islamic and secular ideology, particularly under the Suharto administration, (which had insisted that Pancasila be the sole ideology of the country) caused several rebellions, riots, and political repression. By political marginalisation and military repression, the authoritarian regimes tried to eradicate Islam from the country's political life.

21 Furthermore, the PKS opines that in the country's official history, Islam was marginalised and deprived from having a significant role in the construction of modern Indonesia because, according to them, the development of modern Indonesian nationalism was, in effect, a further development of proto-nationalism of Islam that was struggling against Dutch colonialism before the spirit of nationalism (secular-nationalism) arose among educated Indonesians. 
Figure 2. Objectification process

\begin{tabular}{|l|l|}
\hline Public-Islam(Muslim society) & Public sphere(the state) \\
\hline Approximately 80 per cent of Muslim population & $\begin{array}{l}\text { Added to by } 20 \text { per cent of non-Muslim } \\
\text { population }\end{array}$ \\
$\qquad \begin{array}{l}\text { Subjective needs of } \\
\text { Muslims }\end{array}$ & $\begin{array}{l}\text { Objective needs of } \\
\text { Muslims }\end{array}$ \\
\hline
\end{tabular}

Source: MPP-DPP, Memperjuangkan masyarakat madani, edited by MPP-DPP (Jakarta: MPPPKS, 2008:73).

Hence, the process of secularisation that was exercised by the regimes had to be replaced by its competitor, that is, Islamisation. The PKS looks at this as a gradual process of making relevant the universal values of Islam in the public sphere. The masyarakat madani is a religious, civilised society that is developed within the process of Islamisation as exemplified in the Prophetic-Medinan state. The Medinan state was not utopia; it was a rational, objective and constitutional state, with a strong civil society that accommodated pluralism, democratic principles, openness, accountability and piety (morality). The Medinan state was the genesis of making Islamic values relevant at that time and can work even today. In the Indonesian context, the process of making it relevant derives from the objectification of the Muslims' needs in the public sphere, which are pluralist (Aminudin, 2010). ${ }^{22}$ This objectification comes from the subjective needs of Muslims in a public-Islam, which are homogenous in nature (see Figure 2) (MPP-DPP, 2008: 69-74).

Figure 3. Democratisation and Muslim representation (Islamic politics) to reduce Islamic extremism in Indonesia

The influence of Islamic politics

\begin{tabular}{|l|l|l|l|}
\hline \multicolumn{2}{|l|}{} & \multicolumn{1}{c|}{ Strong } & \multicolumn{1}{c|}{ Weak } \\
\hline \multirow{2}{*}{$\begin{array}{l}\text { Extremism and } \\
\text { Jihadism }\end{array}$} & Increase & $\begin{array}{l}\text { Weak representation of Muslims' } \\
\text { necessities and needs will } \\
\text { increase extremism }\end{array}$ \\
\cline { 2 - 4 } & Decline & $\begin{array}{l}\text { Strong representation } \\
\text { of Muslims' necessities } \\
\text { and needs will decrease } \\
\text { extremism }\end{array}$ & \\
\hline
\end{tabular}

Source: MPP-DPP, Memperjuangkan Masyarakat Madani, edited by MPP-DPP (Jakarta: MPPPKS, 2008: 75).

22 For the PKS, pluralism is part of the teachings of Islam and sunnatulläh (natural law given by God), thus it has to be moderate based on the principle of ummatan wasa $\square$ an (middle or moderate society) in a pluralist society. Hence, the movements and policies that are adopted by the PKS are for the attainment of justice ( $\mathrm{ra}$ 'mah li al-'ālaminn) for all Indonesians, believers and non-believers. 
This model, the PKS believes, will meet Muslims' needs. It is about the full participation by Indonesian Muslims that puts Islam as an integral factor in Indonesian political life to make their country strong, respected and prosperous. Furthermore, it is an objectification of the universality of Islamic values for all Indonesians, which is a blessing ( $\mathrm{rahmah}$ ) for the entire universe. In addition, the PKS's involvement in politics is part of this mission to create a better life for Indonesians, particularly those Muslims who have been trapped and frustrated by political radicalism under authoritarian regimes (see Figure 3) (MPP-DPP, 2008: 74-75).

According to Amien Rais, al-Bannā often alternated in his use of the terms al-dawlah alislämiyyah (Islamic state) and ișlāh al-dawlah (reformation of the state). The creation of an Islamic state is interpreted by Amien as a process of replacing a current evil state by the formation of a new Islamic state. This replacement (revolution) derives from a wide distinction of the characteristics of an evil and of an Islamic state. An example of this revolution may be seen in the Iranian revolution when Ayatollah Khomeini destroyed the power of Pahlevi (Rais, 1999: 49). However, Amien's interpretation is misleading; indeed, the discussions of an Islamic state were originated earlier by Rashīd Ridhā (d. 1935), in the al-Manār journal, to restore Muslim institutions after the collapse of the Ottoman empire (Engineer, 1985: 107). Second, the reformation of the state is a gradual process, which leads to the reform of a fāsiq (godless) governance to an Islamic one (Rais, 1999: 49). This is about a bottom-up Islamisation, which follows the dimensions of da wa (maḥāwir al-da $w a$ ). However, al-Bannā clearly stated that the Muslim Brotherhood does not believe in revolutionary action, for it produces an instant, but not comprehensive, reform of the state (al-Bannā, 2007: 235236; al-Qarḍāwī, 1983: 107; Hawa, 1988: 59). He believed that a gradual reform (Islamisation) is the best path for majority-Muslim states such as Egypt and Indonesia. Al-Bannā's standpoint is reflected in his five da wa methods, which are to ensure that all those variations follow the bottomup strategy following the steps of da wa (Hawa, 1988: 174-177).

Principally, the PKS endorses and applies the concept of Hasan al-Bannā's ișlāh al-dawlah (reformation of the state), not of creating al-dawlah al-islamiyyah (Islamic state), in which the party, based on its official statement, constitutionally submits itself to the Republic of Indonesia (NKRI). Here, Martin van Bruinessen (2003) opines in a moderate standpoint that

...the Partai Keadilan Sejahtera (PKS) is even more 'fundamentalist' in inspiration, but...I believe its engagements with civil society and democracy may in fact contribute to democratisation (or come to the defence of a fragile democracy against new authoritarian tendencies) rather than being a threat to it. It is not the party's theoretical ideas about divine versus human sovereignty that will determine its democratic performance, but its acceptance of the rules of the game and the fact that it is a rational and 'rationalised' organisation (van Bruinessen, 2003).

\section{THE CHALLENGES OF $S H A R \bar{I}^{c} A$ IMPLEMENTATION}

Most revivalist movements view $\operatorname{shari}^{c} a$ as one of their important goals, for instance, the Muslim Brotherhood had it as one of its political missions (Prayitno, 2002: 2; Al-Bannā, 2007: 184-192). Politics is not something deeply legitimate but, at best, it is an instrument that may be useful in gaining power to build a $\operatorname{shari~}^{c} a$-based state (Nasr, 2005) because Islam is an organic religion that provides an understanding of the universal role of religion in social and political life (Hosain, 2003: $38-43){ }^{23}$

23 As an organic religion, Islam is not a structured religion that has a mosque hierarchy and priestly class. Instead, it is an organic religion based on the sacred law (divine law); possessing a comprehensive code of ethics for individuals and society and is religious and social. It drives the political institution to promote Islamic values, and the state is one of the political instruments in which shari $\square a$ could be implemented. Islam becomes a motor to ensure that Muslims do not remain politically backward. 
In many ways, the implementation of $\operatorname{sharl}^{c} a$ is understood to include the strict and bloody physical punishments (that is, ḥudūd, rajm and qișa $\bar{s}$ ). This arouses the suspicion among Indonesians that any revivalist institution or party has an intention to unilaterally implement $\operatorname{shari}^{c} a$ law when in power. Anis Matta distinguishes four myths of $\operatorname{shari}^{c} a$ implementation among Indonesians. The first is that $\operatorname{shari}^{c} a$ is irrelevant to the complexities and problems of modern life. They impugn the effectivity of Islam and the $\operatorname{shari}^{c} a$ as the way of life for modern society. Second, the $\operatorname{shari}^{c} a$ is an inhumane, old institution, particularly for criminal law (especially hudūd, rajm and qișāss). The most extreme implementation for criminal law is in the administration of rajm for zina (adultery), which in major Western countries is not a crime. Third, the $\operatorname{shari}{ }^{c} a$ implementation will violate social integration and the spirit of nationalism in a pluralist society such as Indonesia. ${ }^{24}$ Fourth, there is no Muslim country that is a model $\operatorname{shari}^{c} a$-based (Islamic) state that is more prosperous and advanced than the system of governance in countries such as the USA, European countries and Japan (Matta, 2006: 37-43). Matta's four myths are widely believed by Indonesian Muslims and are understood by the PKS to hamper a full understanding of $\operatorname{shari}^{c} a$.

Noorhaidi Hasan (2009) finds the PKS's role in politics and its commitment to $\operatorname{shari}^{-} a$ to be quite interesting. However, he seems suspicious that the party is ambiguous in bridging Islam, $\operatorname{shari}^{c} a$ and democracy. He states that

...the PKS's reluctance to stand at the forefront to call for the application of the $\operatorname{shari}^{c} a$ bylaws is clearly shaped by its sense of insecurity in the face of the society and the outside world, which remain suspicious of its hidden agenda to transform the secular format of Indonesia to a fully Islamic state.

Hasan has reasons for this assertion. Despite the party's commitment to civility by playing a democratic role and advocating civil rights, it maintains Islam and $\operatorname{shari~}^{c} a$ implementations among its cadres as a source of political identity and legitimacy. Furthermore, the party consistently implements $d a \mathcal{F}_{w a}$ as a complementary strategy to dominate the Indonesian political landscape. His reasons are based on an assumption that most militant Islamist groups are at the forefront of a comprehensive implementation of $\operatorname{sharī}^{c} a$ (Hasan, 2007).

Hasan's argument can be compared to Hilmi Aminudin's position, who opines that it is clearly impossible for the PKS and, indeed, for all Muslims, to ignore the $\operatorname{sharl}^{-} a$ because it is the cornerstone of the Muslim faith (the essence of Islam, esensi Islam). There are two kinds of $\operatorname{shari}^{c} a$; one that has to be implemented by individuals and the other by the state. The former comprises the religious rituals ( $i b \bar{a} d a h$ ), such as șalatt, șawm (fasting) and zakāt; the latter is basically the hudūd, for example, rajm and qișās, which constitute only two per cent of the total body of the $\operatorname{shari~}^{c} a$. Nonetheless, they are consistently dismissed by some superficial campaigns that conceal the greater essence of the $\operatorname{shari}^{c} a$, which promotes justice and humanity. At the state level, the $\operatorname{shari}^{c} a$ has to be objectified under the state's constitution that follows the need and agreement of the people (alBannā, 1983: 198-200). ${ }^{25}$ If there is any opposition to these aspects (hudūd, rajm or qișāss), they cannot be implemented by the PKS (Aminudin, 2010). ${ }^{26}$

24 This assumption is based on the country's experience over the 'seven words', which are deleted from the Pancasila. The Muslims' struggle to insert the word 'shari $\square a$ ' in the Pancasila was seen as disrespectful to non-Muslims and not in line with the spirit of nationalism.

25 The controversy between a state constitution and Islamic law is also addressed by 'asan al-Bannā. Principally, he explains that the Muslim Brotherhood supports constitutional government. However, in the case of the Egyptian constitution, he realises that there are some ambiguities and implementation problems. Interestingly, he prefers moderation in the reformation of the constitution. He says that the attention and objection to the problems are the real value of reformation in which the members have to have a gradual method of treatment and to be concerned about these constitutional problems.

26 The PKS's standpoint is well explained by Yūsuf al-Qar'āwī. He opines that, according to 'asan al-Bannā, the problem has to have a solution that is less damaging than the problem itself. It means, under some conditions, that 
Hilmi's discourse seems to advocate the basic right of Muslims (including the PKS's cadres) to practice the $\operatorname{shari}^{c} a$, being essential to their faith and religion. Thus, he maintains, at the state level, the implementation of $\operatorname{shari}^{c} a$ follows the democratic discourse through political bargaining and commitment to the constitution. He seems to emphasise that it is not devious (a hidden agenda) but it is about advocating the rights of Muslims in politics based on constitutional procedures.

Furthermore, the PKS argues that, for Indonesia, the dialectic between the state and $\operatorname{shari}^{c} a$ is not simply about an Islamic state that implements $\operatorname{shari~}^{c} a$ or a secular state that rejects it. It is about Indonesia, a pluralist society, which comprises numerous ethnic, religious, language and cultural groups, a viable madani (civil) society (masyarakat madani), which should protect all religions that share the universal values of humanity within constitutional and democratic principles (MPP-DPP, 2008: 70-72). In masyarakat madani, the $\operatorname{shari~}^{c} a$ will be substantially adapted to the constitution within the process of Islamisation (see Figure 1) by accommodating the principles of pluralism and democracy, openness, accountability and piety (morality) within the spirit of Islam (al-ukhuwwah alislämiyyah), nationalism (al-ukhuwwah al-wațaniyyah) and humanity (al-ukhuwwah al-bashariyyah) (MPP-DPP, 2008: 203-206).

The PKS tries to connect $\operatorname{shari}^{c} a$ and the state in the most realistic way; that an Islamic state is not necessarily the essence but is about the substance of $\operatorname{sharl}^{-} a$ (universal Islamic values) such as fairness, integrity, effective and clean governance, anti-corruption, the fight against evil and crime and more, that have to be reflected and implemented for the greater good of Indonesia. The formalisation of $\operatorname{shari}^{c} a$ in the constitution without Muslims' readiness to implement it in real life might desecrate Islam itself (DPP-PKS, 2007a: 13). As long as the implementation of $\operatorname{shari~}^{c} a$ is not coerced, and does not violate human rights, the party will reflect the principles of democracy.

\section{CONCLUSION}

Ideologically, the PKS is a moderate party. The willingness of the party to transform itself from a pure $d a{ }^{w}$ a institution to a political party is a reflection of its real political character, which is an unstated constituent of the ideology of the party. This political drive can be logically connected to its home ideological base, the Muslim Brotherhood of Egypt, which is reflected in the thought of the ideologue and founding father of the institution, Hassan al-Bannā. Even though the party is ideologically close to the Muslim Brotherhood, in the Indonesian context, the party is able to contextualise its ideology in approaching democracy. Its approach to $\operatorname{sharl}^{c} a$ implementation is rationally and fairly adhered to within the logic of democratic processes and it tries to avoid coercive policies that might lead to human rights violations.

The party's approach to democratic conventions is part of its grand design for social transformation in which its understanding of Islam will be contextualised within the political and social conditions of contemporary Indonesia. The long history of intrigue underlying the relations between Indonesian Muslims and the State on the issue of secularisation and authoritarian regimes (the case of Indonesia during the New Order of Suharto) engaged the Muslim attitude to change (Esposito, 1998: 214-219; Dessouki, 1982: 22-25). Change is driven by the ability of Muslims in the process of 'objectification' of problems that creates a consciousness among them in actions and beliefs to advocate authentic Islam, which is naturally democratic (Eickelman and Piscatory, 2004: 37-45). Hefner (2000: 3) argues that the ability of Muslims in the process of 'objectification' of problems is stimulated by the process of globalisation (international influences from Middle Eastern Islamic revivalism) that enabled the 'localisation' of Islamic revivalism. This phenomenon becomes a paradox in which modernisation fertilises the wave of revivalism. In very nature of institutional behaviour is not necessarily created to be socially efficient, but the political process creates the

being silent about evil is very necessary if any confrontation with evil will result in greater harm. The unity and togetherness of the ummah is more important (al-Qar'āwī 1983:127-128). 
interest of bargaining power that shapes the direction of institutional change (North, 1990: 82, chapters 2,4).

\section{BIBLIOGRAPHY}

\section{Books}

Ahmad, Mumtaz. (1994). 'Islamic fundamentalism in South Asia: the Jamaat-i-Islami and the Tablighi Jamaat of South Asia'. In Matin E. Marty and R. Scott Appleby (eds.) Fundamentalisms Observed. Chicago: Chicago University Press.

Alfian, Ibrahim. (1987). Perang di jalan Allah. Jakarta: Pustaka Sinar Harapan.

Aminudin, Hilmi. (2008). 'Kata pengantar'. In Memperjuangkan masyarakat madani, edited by MPP-DPP. Jakarta: MPP-PKS.

al-Bannā, Hasan. (1983). Selected writings of Hasan al-Bannā, edited by S.A. Qureshi. Karachi: International Islamic Publishers.

al-Bannā, Hasan. (2007). Majmū ${ }^{c}$ ah al-Rasā'il: kumpulan risalah dakwah Hasan al-Bannā, Vol. 1. Jakarta: Al-I’tishom.

Damanik, Ali Said. (2002). Fenomena Partai Keadilan: transformasi 20 tahun gerakan tarbiyah di Indonesia. Bandung: Mizan.

Dessouki, Ali E Hillal. (1982). 'The Islamic resurgence: sources, dynamics, and implications'. In Ali E Hillal Dessouki (ed.). Islamic resurgence in the Arab world. New York: Praeger.

DPP PKS. (2007a). Dari kader untuk Bangsa; refleksi dan wacana perjuangan kader-kader PKS. Bandung: Fitrah Rabbani.

DPP PKS. (2007b). Mereka bicara PKS: telaah objektif perjalanan dakwah politik PKS. Bandung: Fitrah Rabbani.

Eickelman, Dale F and James Piscatori. (2004). Muslim politics. Princeton and Oxford: Princeton University Press.

Engineer, Asqar Ali. (1985). Theory and practice of the Islamic State. Lahore: Vanguard.

Esposito, John L. (1998). Islam and politics. New York: Syracuse University Press.

Festenstein, Matthew and Michael Kenny. (2005). 'Introduction'. In Matthew Festenstein and Michael Kenny (eds.) Political ideologies. Oxford and New York: Oxford University Press.

Gharīsah, 'Alī Muḥammad. (1988). Dakwah dan sang da'i: kharisma Hasan al-Bannā. Selangor: Thinker Library.

Hawa, Sa ${ }^{c} \overline{1} d$. (1988). Membina angkatan mujahid. Selangor: Thinker Library.

Hefner, Robert W. (2000). Civil Islam: Muslims and democratization in Indonesia. Princeton and Oxford: Princeton University Press.

Hilmy, Masdar. (2010). Islamism and democracy in Indonesia: piety and pragmatism. Singapore: ISEAS.

Hosain, Mir Zohair. (2003). Global Islamic politics, 2nd edn. New York: Longman.

Huntington, Samuel P. (1996). The clash of civilizations and the making of world order. New York: Simon and Schuster.

'Idad, Abu. (1999). Agenda dakwah: langkah-langkah dakwah manhaji. Solo: Al-Aqwam. 
Lewis, Bernard. (2002). What went wrong? The clash between Islam and modernity in Middle East. New York: Oxford University Press.

Matta, M Anis. (2002). Menikmati demokrasi: strategi dakwah dan meraih kemenangan. Jakarta: Pustaka Saksi.

Matta, M Anis. (2006). Dari gerakan ke negara: sebuah rekonstruksi negara madinah yang dibangun dari bahan dasar sebuah gerakan. Jakarta: Fitrah Rabbani.

MPP-DPP PKS (2008). Memperjuangkan masyarakat madani. Jakarta: MPP-PKS.

North, Douglas Cecil. (1990). Institutions, institutional change and economic performance. Cambridge: Cambridge University Press.

Nu'man, Farid. (2003). Al-Ikhwān al-Muslimūn: Anugerah Allah yang Terzalimi. Depok: Pustaka Nauka.

Prayitno, Irwan. (2002). al-Tarbiyah al-Islämiyyah al-Harakiyyah. Jakarta: Tarbiyatuna.

al-Qarḍāwī, Yūsuf. (1983). Sistem pendidikan ikhwanul Muslimin. Jakarta: Media Dakwah.

al-Qarḍ̄āī, Yūsuf. (1997). Fiqih daulah dalam perspectif Al-Qur'an and sunnah. Jakarta: Pustaka al-Kautsar.

al-Qardāwī̄, Yūsuf. (2003). The eye of the beholder: the Muslim Brotherhood over the past 70 years. Cairo: al-Falah Foundation.

Rais, Amien. (1999). Cakrawala Islam: antara cita dan fakta. Bandung: Mizan.

Ridho, Abu. (2004). 'Amal siyasi: geraksn politik dalam dakwah. Bandung: Syaamil,

Sartori, Giovanni. (2005). 'Politics, ideology and belief systems'. In Matthew Festenstein and Michael Kenny (eds.). Political ideologies. Oxford and New York: Oxford University Press.

van Dijk, Kees. (2007). The Netherlands Indies and the Great War 1914-1918. Leiden: KITLV.

Weber, Max. (1974). The Protestant ethic and the spirit of capitalism. London: Allen and Unwin.

Articles, dissertations and working papers

Al Braizat, Fares. (2002). 'Muslim and democracy: an empirical critique of Francis Fukuyama's culturalist approach'. International journal of comparative sociology, 43(3-5): 271.

Benda, Harry J. (1955). 'The crescent and the rising sun: Indonesian Islam under the Japanese occupation of Java, 1942-1945'. Unpublished Ph.D. dissertation, Cornell University.

Bruinessen, Martin van. (2003). Post-Suharto Muslim engagements with civil society and democratization. Unpublished Paper in Third International Conference on Indonesia in Transition, Indonesian University, 24-28 August.

Bubalo, Anthony and Greg Fealy. (2005). Between the global and the local: Islamism, the Middle East, and Indonesia. Saban Centre Analysis Paper Number 9.

Hasan, Noorhaidi. (2007). 'Islamic militancy, $\operatorname{shari}^{c} a$, and democratic consolidation in post-Suharto Indonesia'. RSIS Working Paper No. 143, Nanyang Technological University.

Hasan, Noorhaidi. (2009). 'Islamist party, electoral politics and da wa mobilization among youth: the Prosperous Justice Party (PKS) in Indonesia'. RSIS Working Paper, Vol. 184, Nanyang Technological University. 
Hasenclever, Andreas and Volker Rittberger. (2000). 'Does religion make a difference? Theoretical approaches to the impact of faith and political conflict'. Millennium: Journal of international studies, 29, No.3: 641-674.

Hikam, Muhammad AS. (1999). 'Wacana intelektual tentang civil society di Indonesia'. Paramadina, 1(2).

Madjid, Nurcholis. (1996). 'Menuju masyarakat madan'. Ulumul Qur'an, 7(2).

Moten, Abdul Rashid. (1993). Politics: an Islamic Perspective. Intellectual Discourse, 1(1): 28-45.

Nasr, Vali. (2005). 'The rise of Muslim democracy'. Journal of democracy,16(2): 13-27.

Stepan, Alfred and Graeme B. Robertson. (2004). 'Arab, Not Muslim, Exceptionalism'. Journal of democracy, 15(4): 140-146.

Websites

Aminudin, Hilmi. (2010). 'Kami ingin membangun kebersamaan dalam keragaman'. Republika online, 22 June 2010, 5. <http://republika.co.id:8080/koran/124/113605> (accessed 22 June 2010).

Fealy, Greg. July-September. (2010). Front Stage with The PKS. Inside Indonesia, vol. 101 $<\mathrm{http} / /$ www.insideindonesia.org/stories/front-stage-with-the-pks-04091353> (accessed 29 December 2010)

The Tarbiyah weekly, Agenda Tarbiyah di Era al-Jahriyyah al-Jamāhiriyyah: Perbesar Kualitas, Perbanyak Kuantitas, 24 October 2007.

$<$ http://tarbiyahweekly.wordpress.com/2007/10/24/agenda-tarbiyah-di-era-jahriyahjamahiriyah/> (accessed 18 June 2014).

Zulkieflimansyah, Paradigma Partai Keadilan Sejahtera (bagian 1). 4 August 2008, $<$ http://www.zulkieflimansyah.com/in/paradigma-partai-keadilan-sejahtera-bagian-i.html> (accessed 12 October 2010). 
JISSH Volume One 2014 